\title{
THE USE OF MULTIDIMENSIONAL STATISTICAL ANALYSIS METHODS IN THE BURNOUT STUDY OF TEACHERS \\ AND LECTURERS AT UNIVERSITIES
}

\author{
Iwona Bąk, Ph.D., Associate Professor ${ }^{1}$ \\ Katarzyna Wawrzyniak, Ph.D. ${ }^{2}$ \\ Department of Application of Mathematics in Economics \\ Faculty of Economics \\ West Pomeranian University of Technology, Szczecin \\ Janickiego 31, 71-101 Szczecin, Poland \\ 1 e-mail: iwona.bak@zut.edu.pl \\ ORCID: 0000-0001-8959-7269 \\ 2 e-mail: katarzyna.wawrzyniak@zut.edu.pl \\ ORCID: 0000-0003-4161-3877
}

Received 18 October 2019, Accepted 6 April 2020

\begin{abstract}
Research background: The study was conducted and based on the project The assessment of mental condition, financed by the Ministry of Health as part of the National Health Program for 2016-2020 (operational objective 3: Prevention of mental health problems and improvement of mental well-being of society). The article focuses on a group of teachers and university lecturers from eight voivodeships selected for the study, whereas burnout was selected from the areas of mental disorders.

Purpose: The main objective of the study was to identify the regularities in the relationship between the level of professional burnout and selected demographic characteristics in the group of teachers and university lecturers. Additionally, the spatial diversity of the percentage of respondents diagnosed with occupational burnout was examined.

Research methodology: Two methods from the multi-dimensional statistical analysis were used: a classification tree analysis, and a correspondence analysis.

Results: The methods used allowed to classify the studied professional group in terms of the degree of occupational burnout. The results obtained using both the classification trees and multidimensional correspondence analysis allowed the identification of similar regularities regarding the impact of demographic variables on the level of occupational burnout.
\end{abstract}


Novelty: The application of multidimensional statistical analysis methods to study mental health based on individual, unique data from eight Polish voivodeships.

Keywords: the assessment of mental condition, teachers and lecturers at universities, burnout, multi-dimensional correspondence analysis, and classification trees

JEL classification: C38, I12

\section{Introduction}

The Association "Czas Przestrzen Tożsamość" with its seat in Szczecin conducted the project The assessment of mental condition, financed by the Ministry of Health as part of the National Health Program for 2016-2020 (operational objective 3: Prevention of mental health problems and improvement of mental well-being of society). The project covered eight Polish voivodeships (Dolnośląskie, Kujawsko-pomorskie, Lubuskie, Łódzkie, Opolskie, Śląskie, Wielkopolskie and Zachodniopomorskie) and its main goal was to assess the mental condition of socio-occupational groups particularly exposed to stress and depression related to their profession, such as students, administration employees, uniformed services employees, teachers and lecturers from universities, doctors and other employees of the healthcare system, and social workers. The study was carried out using a self-diagnosis tool, ${ }^{1}$ which indicates seven areas of mental disorders including somatic disorders, sleep problems, burnout, mood disorders, behavioral addictions, mobbing, and eating disorders.

In the period from January 1 to December 31, 2018, 107,423 people from all over the country participated in the study, including 99,584 ( $92.7 \%$ of all respondents) diagnosed persons from the eight target voivodeships.

The article focuses on the group of teachers and lecturers from the higher education institutions from the target voivodeships (12,391 people, i.e. $11.5 \%$ of all respondents), whereas occupational burnout was selected from the areas of mental disorders, which limited the surveyed population to 11,642 people. The choice of this professional group and this area of disorders was dictated by the desire to check what percentage of people in this group have problems with occupational burnout and which demographic characteristics significantly affect its level. Obtaining answers to these questions is particularly important at the time of introducing education reform in both primary and secondary schools, as well as in higher education. New

\footnotetext{
1 The tool is available on the project website: www.zdrowiepsychiczne.org.
} 
teaching principles and major organizational changes in education require personal commitment on the part of teachers, and this can be difficult in the case of burnout problems.

Burnout as noted by A. Bańka (2000) is the body's emotional response in a stressful situation, which creates a requirement for constant concentration on other people's problems at work. Ch. Maslach and S. Jackson (1986) define burnout as "a psychological syndrome of emotional exhaustion, depreciation and a reduced sense of personal achievement that can occur in people working with other people in a certain way". Burnout syndrome is an individual trait, which is the result of an imbalance between the level of requirements for the individual and his/her ability to cope with workloads. H. Freudenberger and G. North (2002) distinguished as many as 12 stages of this process, ranging from the need to constantly prove their own worth to full-blown burnout, i.e. mental, physical and emotional fatigue. Research conducted in European Union countries indicates that almost 30\% of employees observe the destructive impact of professional activity on their psychophysical condition (Paoli, 1997). As numerous scientific research shows, the negative effects of burnout have a big impact on labor productivity and can cause serious health problems (Leiter et al., 1998; Nahrgang et al., 2011; Ostrowska, Michcik, 2013; Smith et al., 2019) and also spread to all areas of life, including home, work and social life (Smith et al., 2019). Therefore, it is often emphasized in the literature that conducting multidisciplinary research on burnout syndrome is becoming increasingly important, because in addition to the undoubted difficulties and suffering of people experiencing the symptoms of this phenomenon, there are significant social costs associated with the reduced quality and efficiency of their work (Anczewska et al., 2005).

Other studies confirm that occupational burnout leads to numerous, well-established disorders in the psychological, social, but also physiological functioning of the individual (Maslach, Leiter, 2001; Schaufeli, Bakker, 2004). The feeling of physical and mental exhaustion is particularly important for the decrease in the employee's health. Negative effects of burnout are also visible in the professional sphere. Employees with advanced burnout syndrome have different ways to withdraw from work and roles. They can take the form of absenteeism at work, reduction of working time, or readiness to quit (Maslach, Leiter, 2001; Bakker et al., 2003).

Professional burnout among teachers is an important social and pedagogical problem. Frequent occurrence of tension and stress in generally difficult working conditions causes emotional exhaustion and reduces the motivation and involvement of teachers in matters of the school and the local environment. The intensity of occupational burnout has a major impact on the functioning of teachers in all spheres of life. It decides on relations with students, colleagues, co-workers, and superiors. It also determines family functioning, frequent conflicts, and 
irritations. Ch. Maslach (1998) treats them as a crisis of professional activity caused by a lack of matching between a person and work in a broad sense (also as an organization). The greater the mismatch between a person and work, the greater is the likelihood of burnout (Maslach, Leiter, 2001).

Due to the great importance of the problem posed by burnout, it seems necessary to conduct research on this phenomenon, also among academic teachers. Despite the significant number of work on the burnout of teachers, relatively few of them were devoted to teachers of universities, whose primary task is academic work, and therefore work that does not always require contact with people as recipients of services. In addition, university employees also remain teachers (Świętochowski, 2011).

The article presents the results of the research whose main objective was to identify the regularities in the relationship between the level of professional burnout and selected demographic characteristics in the study group of teachers and lecturers. Moreover, it will examine the spatial diversity of the percentage of respondents who were diagnosed with professional burnout.

In order to obtain the main objective, two multi-dimensional statistical analysis methods were used: a classification tree analysis and a correspondence analysis. The first one allowed classifying respondents from the studied professional group from the point of view of the level ofoccupationalburnoutwithsimultaneousconsiderationofdemographiccharacteristics. Thesecond one allowed checking which variants of demographic characteristics are related to the degree of professional burnout.

The choice of these methods was not accidental, because in numerous works the examples of their applications can be found both for grouping (segmentation) of objects, as well as for testing the coexistence of variable categories. The use of classification trees for the segmentation of objects can be found, among others, in the works of (Bąk, Wawrzyniak, 2010 - the segmentation of households of pensioners due to the type of tourist trips), (Batóg et al., 2011 - the segmentation of households due to demand realized on the market of life insurance), (Dudek, 2011 - the classification of borrowers of German banks based on selected symbolic variables), (Matczak, Kozłowski, 2013 - the detection of factors affecting parents' educational aspirations).

However, the examples of the applications of multidimensional correspondence analysis can be found, among others, in the following works: (Autiero et al., 2000), (Bąk, Wawrzyniak, 2009), (Batóg et al., 2009), (Ezzari, Verme, 2012), (Cheba, Hołub-Iwan, 2014), (Dębkowska, Kilon, 2014), (Batóg, Batóg, 2016), (Bąk et al., 2019). 


\section{Material characteristics and research method}

The basis for the assessment of mental health is a tool for the self-diagnosis of mental health prepared by a team of Szczecin psychologists and psychiatrists, which, after approval by the Ministry of Health, was tested on a control sample in the fourth quarter of 2017. The developed tool for self-diagnosis is a test consisting of several dozen questions, with a different set of questions for each area of mental disorders. ${ }^{2}$ In the case of occupational burnout, the test/ survey consists of 7 questions with specific answer options (Table 1). The variants of responses were assigned numerical values ( 0 or 1$)$ resulting from the assessment of their significance for the mental condition of the subjects. After completing the questionnaire, the points assigned to the selected options are added together and this sum determines the degree of burnout of the respondent. Due to the number of questions possible to get the sum of points is from 0 to 7 . If the sum of points does not exceed three (non-reference values), the respondent is not at risk of professional burnout. However, if the sum of points is at least equal to 4 (reference values), then the respondent has problems with professional burnout ${ }^{3}$. In this way, a dichotomous dependent variable with variants: no burnout and occupational burnout was obtained. In addition, the researchers assumed that a sum of points equal to 4 or 5 indicates low occupational burnout, while equal to 6 or 7 indicates high occupational burnout. Thus, another dichotomous dependent variable with variants: low occupational burnout and high occupational burnout was obtained. The first dependent variable characterizes all respondents, while the second - only those for whom burnout was diagnosed.

Table 1. Questions included in the survey questionnaire with the numerical values assigned to variants of responses

\begin{tabular}{|c|c|c|c|c|}
\hline \multirow{2}{*}{ Have you in the last 6 months } & \multicolumn{4}{|c|}{ Numerical values assigned to variants of responses } \\
\hline & 0 & 0 & 1 & 1 \\
\hline 1 & 2 & 3 & 4 & 5 \\
\hline Performed your daily activities and duties? & $\begin{array}{c}\text { Better } \\
\text { than usual }\end{array}$ & As usual & $\begin{array}{c}\text { Worse } \\
\text { than usual }\end{array}$ & $\begin{array}{c}\text { Much worse } \\
\text { than usual }\end{array}$ \\
\hline Been satisfied with the quality of your work? & $\begin{array}{c}\text { More } \\
\text { than usual }\end{array}$ & As usual & $\begin{array}{c}\text { Less } \\
\text { than usual }\end{array}$ & $\begin{array}{l}\text { Much less } \\
\text { than usual }\end{array}$ \\
\hline Felt that what you have been doing makes sense? & $\begin{array}{c}\text { More } \\
\text { than usual }\end{array}$ & As usual & $\begin{array}{c}\text { Less } \\
\text { than usual }\end{array}$ & $\begin{array}{l}\text { Much less } \\
\text { than usual }\end{array}$ \\
\hline $\begin{array}{l}\text { Been irritated by people with whom you have contact } \\
\text { at work/at school/ during the performance of official } \\
\text { duties/in a clinic, office, hospital? }\end{array}$ & Not at all & As usual & $\begin{array}{c}\text { More } \\
\text { than usual }\end{array}$ & $\begin{array}{l}\text { Much more } \\
\text { than usual }\end{array}$ \\
\hline
\end{tabular}

\footnotetext{
2 A detailed description of how to build a mental health self-diagnosis tool is presented in the work of (Durka, 2018).

3 Non-referenced values indicate acceptable values that do not endanger the subject, and reference values mean that the subject should take steps to further diagnose his/her situation based on specialist assistance.
} 


\begin{tabular}{|l|c|c|c|c|}
\hline \multicolumn{1}{|c|}{1} & 2 & 3 & 4 & 5 \\
\hline Felt joy and satisfaction at work? & $\begin{array}{c}\text { More than } \\
\text { usual }\end{array}$ & As usual & $\begin{array}{c}\text { Less } \\
\text { than usual }\end{array}$ & $\begin{array}{c}\text { Much less } \\
\text { than usual }\end{array}$ \\
\hline Felt reluctant before going to work? & No & As usual & $\begin{array}{c}\text { More } \\
\text { than usual }\end{array}$ & $\begin{array}{c}\text { Much more } \\
\text { than usual }\end{array}$ \\
\hline $\begin{array}{l}\text { Felt anxiety when contacting patients/when contacting } \\
\text { students and their parents/during the performance } \\
\text { of official tasks/when contacting pupils? }\end{array}$ & no & $\begin{array}{c}\text { No more } \\
\text { than usual }\end{array}$ & $\begin{array}{c}\text { More } \\
\text { than usual }\end{array}$ & $\begin{array}{c}\text { Much more } \\
\text { than usual }\end{array}$ \\
\hline
\end{tabular}

Source: own study based on Durka (2018).

Due to the research objectives and the nature of dependent variables and independent variables (gender, age, ${ }^{4}$ place of residence - voivodeships), ${ }^{5}$ two multidimensional statistical analysis methods were used in the study: a classification tree and correspondence analyses. In the case of classification trees, two nominal dichotomous variables were considered - the first had categories: non-burnout and occupational burnout and the second: low and high occupational burnout. However, in correspondence analyses together with the variables gender, age and place of residence, the variable sum of points (eight categories: 0, 1, 2, 3, 4, 5, 6, 7) was used.

Theoretical considerations regarding classification trees can be found in the following works: Gatnar, 2001; Gatnar, Walesiak, 2004; Gatnar, 2008; Gatnar, Walesiak, 2009. Based on this work, it was assumed that the classification and regression trees are a graphic representation of the model:

$$
Y=f\left(\mathbf{x}_{i}\right)=\sum_{k=1}^{K} \alpha_{k} \boldsymbol{I}\left(\mathbf{x}_{i} \in R_{k}\right)
$$

where: $Y$ - dependent variable, $R_{k}(k=1, \ldots, K, K$ - number of segments) are subspaces (segments) of independent variable spaces $\mathbf{X}^{L}=\left(X_{1}, X_{2}, \ldots, X_{L}\right) ; L-$ number of independent variables; $\mathbf{x}_{\mathrm{i}}=\left[x_{i 1}, x_{i 2}, \ldots, x_{i L}\right]-$ observations from a recognizable set; $\alpha_{k}$ - model parameters; $\boldsymbol{I}$ - indicator function.

The method of determining parameters $\alpha_{k}$ defining the subspace $R_{k}$ and assessing the quality of the space division of independent variables $\mathbf{X}^{L}$ depends on the nature of both dependent and independent variables.

\footnotetext{
4 Age in the survey questionnaire was given in the form of bands on the basis of which three categories were created (up to 40 years, 40-60, 60 years and more).

5 All independent variables are nominal: gender has two categories (male, female), age - tree categories (compare footnote number 4), place of residence - eight categories (voivodeships: Dolnośląskie, Kujawsko-pomorskie, Lubuskie, Łódzkie, Opolskie, Śląskie, Wielkopolskie, Zachodniopomorskie).
} 
If the dependent variable $Y$ in the model (1) is a nominal variable, then this model is called discriminatory and is represented by a classification tree. Parameters $\alpha_{k}$ for this model are designated as

$$
\alpha_{k}=\underset{j}{\arg \max } p\left(C_{j} / \mathbf{x}_{i} \in R_{k}\right)
$$

where $p\left(C_{j} / \mathbf{x}_{i} \in R_{k}\right)$ means probability a posteriori that observation from segment $R_{k}$ belongs to class $C_{j}$.

If the variables $X_{1}, X_{2}, \ldots, X_{L}$ are non-metric, the subspace $R_{k}$ can be defined as

$$
\boldsymbol{I}\left(\mathbf{x}_{i} \in R_{k}\right)=\prod_{l=1}^{L} \boldsymbol{I}\left(x_{i l} \in B_{k l}\right)
$$

where $B_{k l}$ is a subset of the variable category set $X_{l}$, i.e. $B_{k l} \subseteq V_{l}$.

To assess the quality of the space division of explanatory variables $\mathbf{X}^{L}$ for a non-metric dependent variable the following measures are used: classification error, Gini index, entropy measure, statistics $\chi^{2}$.

In the article, the multidimensional analysis of correspondence ${ }^{6}$ using Burt's matrix was applied. The procedure followed according to the following stages (Stanimir, 2005):

1. The determination of the real dimension of coexistence space $K$ according to the formula:

$$
K=\sum_{q=1}^{Q}\left(J_{q}-1\right)
$$

where: $J_{q}$ - the number of categories of the variable $q(q=1,2, \ldots, Q){ }^{7} Q-$ the number of analyzed variables.

2. Checking to what extent the eigenvalues of lower dimension spaces explain total inertia (the Greenacre's criterion was used, according to which major inertia greater than $\frac{1}{Q}$ are considered important for the study).

3. Increasing the quality of mapping in two-dimensional space by modifying eigenvalues according to Greenacre's suggestions as follows:

$$
\tilde{\lambda}_{k}=\left(\frac{Q}{q-1}\right)^{2} \times\left(\sqrt{\lambda_{B, k}}-\frac{1}{Q}\right)^{2}
$$

\footnotetext{
${ }^{6}$ More on the nature and applications of multidimensional correspondence analysis can be found in the works by: (Greenacre, 1984, 1993, 1994; Gatnar, Walesiak, 2004; Stanimir, 2005).

7 For example, $J$ for the variable "gender" is equal 2, because "gender" has two categories (male, female).
} 
where: $Q$ - the number of analyzed variables; $\lambda_{B, k}-k$-th eigenvalue $(k=1,2, \ldots, K)$, $\left(\sqrt{\lambda_{B, k}}=\gamma_{B, k}\right) ; \gamma_{B, k}-k$-th singular value of matrix B.

4. Applying the "elbow" criterion to determine the best projection dimension.

5. In the case when the best projection dimension is greater than three, i.e. it is impossible to graphically present the location of the individual categories of examined variables and to interpret the relationships between them on this basis, using the Ward method to group all categories of variables described by the values of dimensions obtained as a result of multidimensional analysis correspondence including modified eigenvalues.

\section{Research results}

Figure 1 shows the percentage of respondents who were diagnosed with the absence or existence of occupational burnout. Most people with problems in this respect were observed in the Wielkopolskie voivodeship (42.2\%), and the least in the Łódzkie voivodeship (8.5\%). In the remaining surveyed voivodeships, the percentage of people diagnosed with occupational burnout ranges from 12.1\% (Lubuskie voivodeship) to 30.3\% (Dolnośląskie voivodeship).

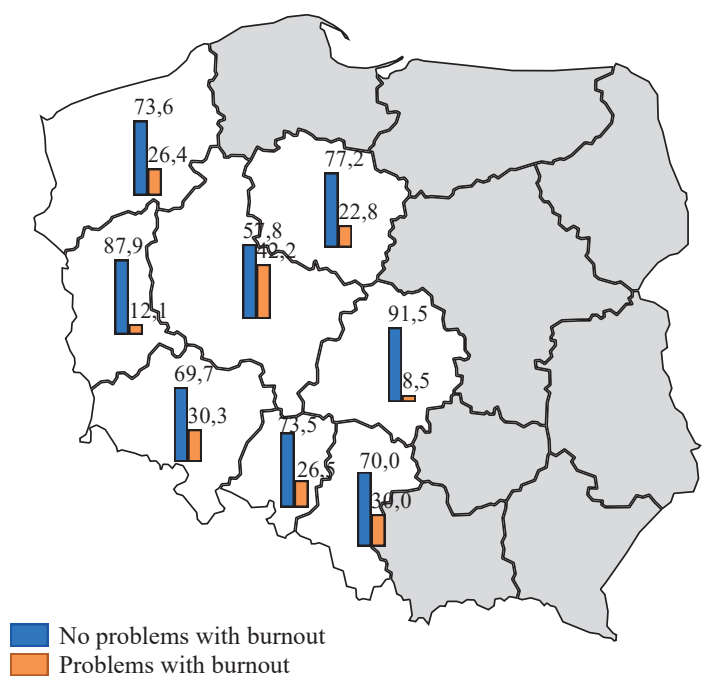

Figure 1. Structure of respondents according to the degree of occupational burnout in the surveyed voivodeships

Source: own study.

The structure of the respondents presented in Figure 1 does not indicate why in individual voivodeships there are differences in the percentage of people with occupational 
burnout. Therefore, in order to identify the variables that may have an impact on the occupational burnout of the respondents it was decided to use a classification tree in which the dependent variable has two variants: no burnout and occupational burnout, and the set of independent variables includes: gender, age and place of residence (voivodeships). To determine the classification trees, CART and CHAID procedures ${ }^{8}$ were used, which are programmed in the Statistica 12.0 package. When choosing between trees obtained on the basis of both procedures, the following aspects were considered: (Bąk, Wawrzyniak, 2009).

- that the selected tree was not very extensive,

- that the criteria for splitting nodes were not repeated in subsequent split nodes,

- that there was a possibility of a logical interpretation of the final results.

It turned out that the tree obtained by the CHAID procedure was very extensive (the number of end nodes ranged to 20 , the criteria for splitting the nodes repeated, the interpretation of results was difficult), while the tree obtained by the CART procedure met the accepted requirements. Using the CART procedure, a sequence of trees is obtained from which the best tree can be selected by analyzing an additional graph showing the level of cross-checking costs and the costs of re-substitution against the background of the complexity of the tree the best is the tree for which the difference between the cost of cross-checking and the cost of re-substitution is the smallest. As a result of this procedure, a sequence of four classification trees was obtained, from which the third tree was selected, because for this tree, the difference between these costs was the smallest.

While interpreting the selected classification tree (Figure 2), the following conclusions were made:

- $90 \%$ of respondents living in the Lubuskie and Łódzkie voivodeships did not have a problem with occupational burnout,

- in the following voivodeships: Dolnośląskie, Kujawsko-pomorskie, Opolskie, Śląskie and Zachodniopomorskie, the lack of burnout affected almost $73 \%$ of respondents,

- respondents residing in the Wielkopolskie voivodeship under the age of 40 who have no problems with occupational burnout and this applies to $66 \%$ of respondents,

- in the case of men aged 40 and more living in Wielkopolska, the problem of burnout concerns almost $64 \%$, while for women from this voivodeship and at the same age, the problem of burnout concerns $41 \%$.

\footnotetext{
8 The algorithm for creating trees with the CHAID and CART (C\&RT) procedure can be found e.g. in the Electronic Textbook StatSoft on the tab CHAID and C\&RT Trees (StatSoft, 2006).
} 


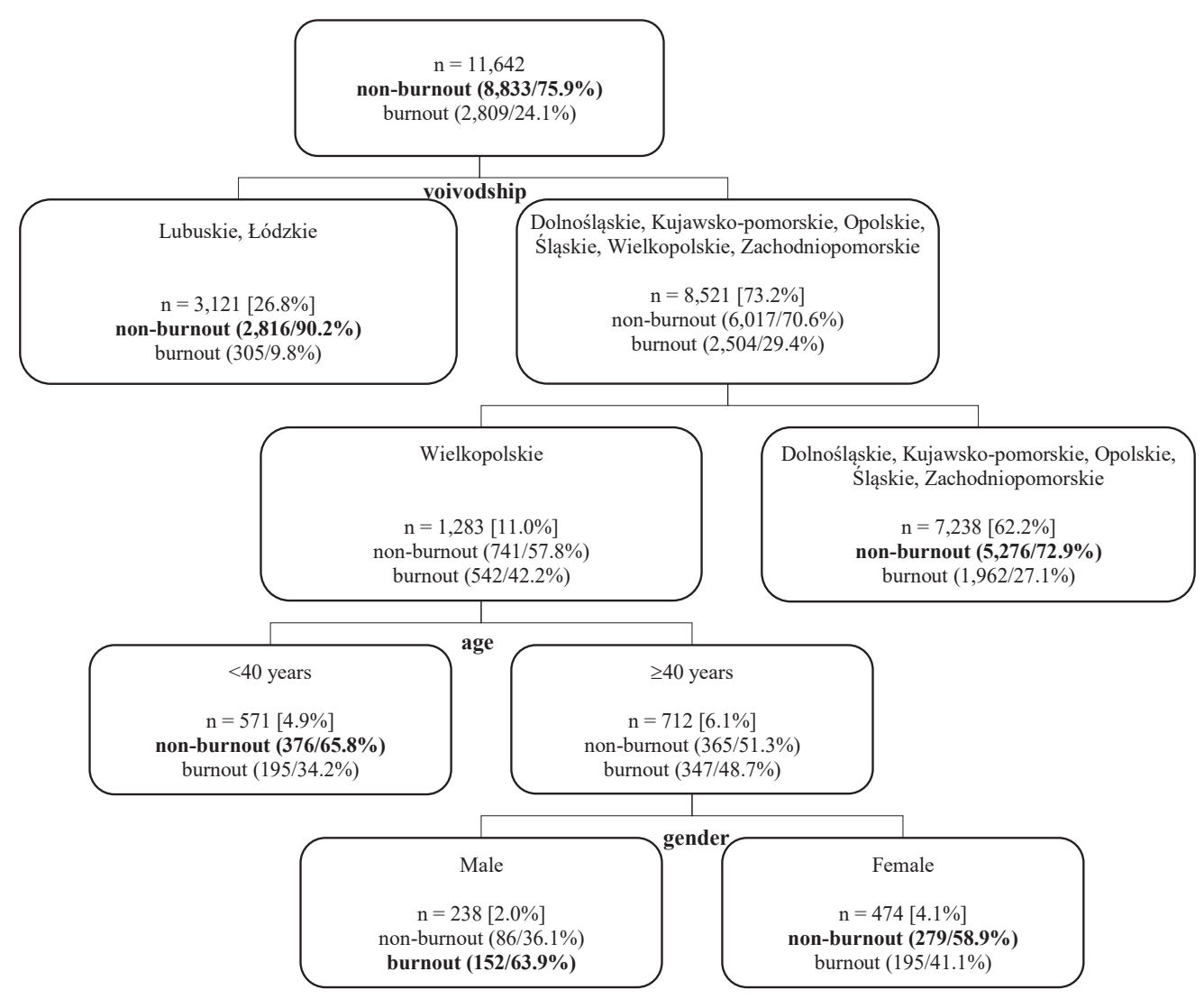

In square brackets, the percentage of respondents in relation to the whole population is given, and in parentheses - next to the number - the percentage in relation to the number in a given node is given.

Figure 2. Classification tree for non-burnout and burnout obtained by the CART procedure Source: own study.

The classification tree presented in Figure 2 concerns the dichotomous dependent variable (the absence or existence of occupational burnout). This variable, as mentioned earlier, was created as the sum of points obtained by the respondent on the basis of the answers given to the questions contained in the questionnaire. In order to check how the independent variables adopted in the study affected the distribution of the points sum, a multidimensional correspondence analysis was used. It was carried out on the basis of a Burt matrix with dimensions $21 \times 21$ formed of categories for the four variables (the symbols of the variable categories are used in Figure 3):

1. Sum of points obtained by the respondent on the basis of the answers given to the questions contained in the questionnaire - eight categories (SP0 - sum of points $=0$, 
$\mathrm{SP} 1-$ sum of points $=1, \mathrm{SP} 2-$ sum of points $=2, \mathrm{SP} 3-$ sum of points $=3, \mathrm{SP} 4-$ sum of points $=4$, SP5 - sum of points $=5$, SP $6-$ sum of points $=6$, SP7 - sum of points $=7)$.

2. Gender - two categories ( $\mathrm{M}$ - male, $\mathrm{F}$ - female).

3. Age - three categories (A1 - under 40 years, A2 - 40-60 years, A3 - 60 years and more).

4. Place of residence - eight voivodeships (DL - Dolnośląskie, KP-Kujawsko-pomorskie, LB - Lubuskie, LD - Łódzkie, OP - Opolskie, SL - Śląskie, WP - Wielkopolskie, ZP - Zachodniopomorskie).

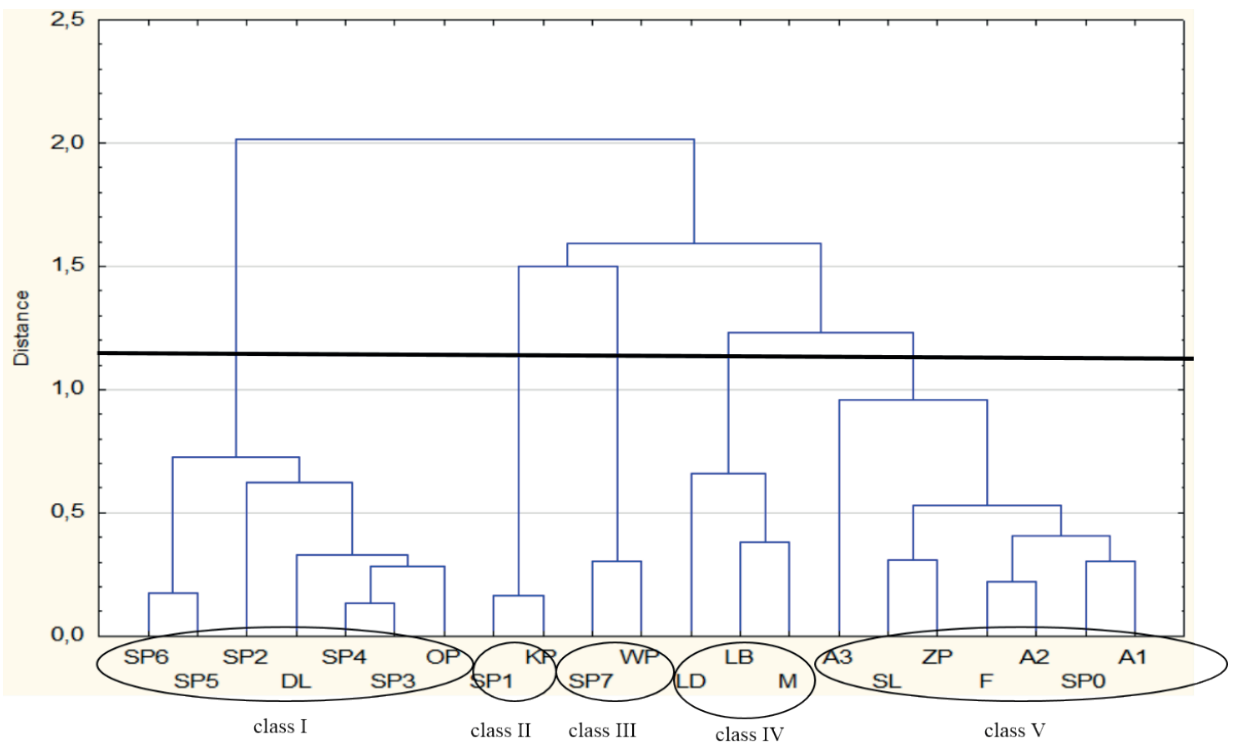

Figure 3. Diagram of a hierarchical classification of variable categories made using the Ward method

Source: own study.

The dimension of the actual space of answers coexistence (formula 4) was 17. Next, it was checked to what extent the eigenvalues of the smaller dimensions explain the total inertia $(\lambda=1.1595)$. For this purpose, the Greenacre criterion was used, according to which major inertia greater than $\frac{1}{Q}=\frac{1}{4}=0,25$ are considered to be significant for the study. It turned out that these are inertia for $K$ with values up to 8. In addition, a graph of eigenvalues was prepared and using the "elbow" criterion, it was found that the space of co-occurrence of variable variants 
should be five-dimensional. For this dimension, the explanation for total inertia was 35.73\%. After the modification of eigenvalues according to Greenacre's suggestions (formula 5), the quality of the mapping was increased to $69.76 \%$. Due to the inability to interpret the results in the five-dimensional space, it was decided to use the Ward method, ${ }^{9}$ which allowed grouping the categories of variables, and thus gave the basis to determine the relationships between them (Figure 3). The horizontal line marked on the graph indicates the stage at which combining classes was aborted. ${ }^{10}$ In this way the following five classes were obtained:

- class I: includes respondents residing in the Dolnośląskie and Opolskie voivodeships who have problems with burnout,

- class II: includes respondents living in the Kujawsko-pomorskie voivodeship who have no problems with burnout,

- class III: includes respondents from the Wielkopolskie voivodeship who have the greatest problems with burnout, which is consistent with previous research results (the highest percentage of respondents with burnout),

- class IV: no relation to the categories of the variable defined as the sum of points,

- class V: applies to women living in the Śląskie and Zachodniopomorskie voivodeships who, regardless of their age, have no problems with burnout.

The final stage of the study was the classification of respondents who had problems related to occupational burnout. Figure 4 presents the classification tree obtained using the procedure CART, which was selected in the same way as for the classification tree presented in Figure 2. From the sequence of nine trees, the fourth tree was chosen for interpretation (Figure 4):

- $57.9 \%$ of the respondents were characterized by severe burnout,

- severe burnout concerned the inhabitants of the Kujawsko-pomorskie, Wielkopolskie and Śląskie voivodeships regardless of gender, in the case of women the greater burnout was recorded in the Śląskie and Wielkopolskie voivodeships, while in the Kujawskopomorskie voivodeship the burnout was higher among young women (under 40 years),

- severe burnout was also observed for respondents living in the Łódzkie and Zachodniopomorskie voivodeships, while it was higher for women aged 40 and more living in the Łódzkie voivodeship,

\footnotetext{
9 The Ward method is one of the agglomerative clustering procedures. It is applied to empirical studies in relation to both the classification of objects and their characteristics. In this method the distance between clusters is defined as a module of difference between the squared distances between points and cluster centers containing these points (Malina, 2004).

${ }^{10}$ In order to divide the dendrogram and determine the number of classes, factor Grabiński (1992) was used: $d_{i}=d_{i} /$ $\left(d_{i}-1\right)$, where $d_{i}$ is $i^{\text {th }}$ distance. The highest value $q_{i}$ indicated the dendrogram division point.
} 
- the smallest burnout concerned the following voivodeships: Dolnośląskie, Lubuskie and Opolskie.

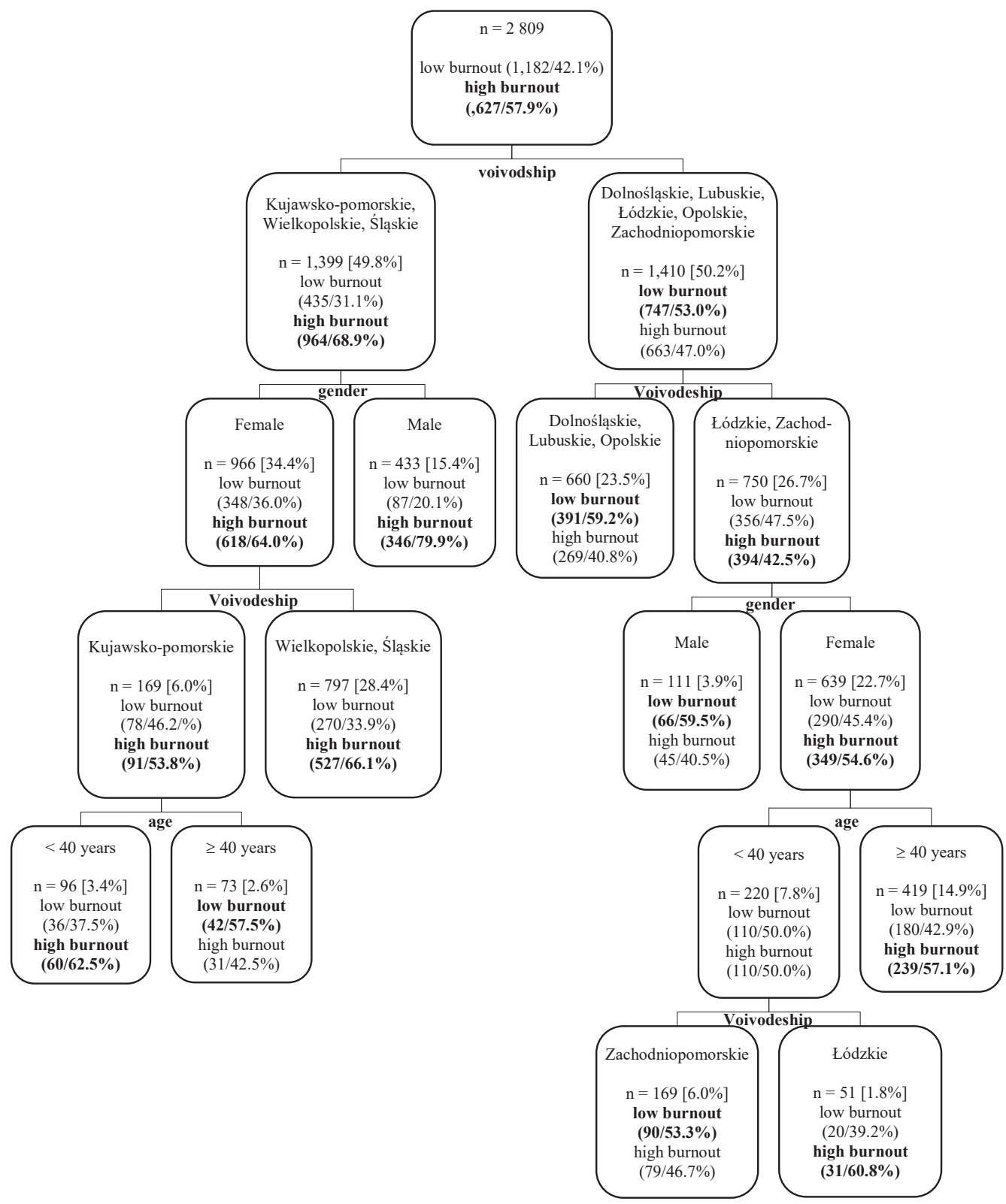

In square brackets, the percentage of respondents in relation to the whole population is given, and in parentheses - next to the number - the percentage in relation to the number in a given node is given.

Figure 4. Classification tree for burnout level obtained by the CART model procedure

Source: own study. 


\section{Conclusions}

The methods used in the study allowed classifying the respondents from the studied professional group in terms of the degree of occupational burnout with simultaneous consideration of gender, age and place of residence. The results obtained by both methods allowed the identification of similar regularities regarding the impact of demographic variables on the level of occupational burnout. On this basis, the following conclusions can be formulated:

1. In all of the surveyed voivodeships there are teachers who, in their assessment, are endangered with the risk of burnout.

2. Most people with occupational burnout were observed in the Wielkopolskie voivodeship and are mainly men aged 40 and more.

3. The least people at risk of burnout are in the Łódzkie and Lubuskie voivodeships.

4. The highest intensity of occupational burnout concerns women living in the Wielkopolskie and Śląskie voivodeships and men living in the Wielkopolskie, Śląskie and Kujawsko-pomorskie voivodeships.

5. Large burnout concerns young women (under 40 years) living in the Kujawskopomorskie voivodeship.

6. The smallest burnout was observed among men from the Zachodniopomorskie and Łódzkie voivodeships and among young women in the Zachodniopomorskie voivodeship.

The conclusions formulated above may be the basis for deeper analyses, which will explain, for example, why in the Wielkopolskie and Śląskie voivodeships professional burnout among teachers and university lecturers is the highest, and in the Lódzkie and Lubuskie voivodeships the lowest. Possibly, this is due to the large differences in employee wages in these voivodeships. Moreover, it would be interesting to check - in the future - whether the problems related to education reform will affect the level of occupational burnout among teachers and university lecturers.

In summary, the problem of professional burnout among teachers still inspires researchers of this phenomenon (Sekułowicz, 2002; Pines, 2004; Sęk, 2004; Zbyrad, 2017). Teachers are included in high-risk groups and therefore further research in this area, e.g. the identification of the factors that generate this phenomenon, is most justified. This article, which identifies the impact of demographic variables on the level of occupational burnout among teachers and university lecturers in eight voivodeships in 2018, should be included in this type of research. 


\section{References}

Anczewska, M., Świtaj, P., Roszczyńska, J. (2002). Wypalenie zawodowe. Postepy Psychiatrii i Neurologii, 14 (2), 67-77.

Autiero, G., Bruno, B., Mazzotta, F. (2000). A Correspondence Analysis of Labour Market Institutions. CELPE Discussion Papers, 57.

Bakker, A.B., Demerouti, E., De Boer, E., Schaufeli, W.B. (2003). Job demands and job resources as predictors of absence duration and frequency. Journal of Vocational Behavior, 62.

Bańka, A. (2000). Psychologia pracy. Wypalenie zawodowe. Psychologia. Podręcznik akademicki. Jednostka w społeczeństwie i elementy psychologii stosowanej, t. 3. Gdańsk: Gdańskie Wydawnictwo Psychologiczne.

Batóg, B., Batóg, J. (2016). Application of correspondence analysis to the identification of the influence of features of unemployed persons on the unemployment duration. Economic and Business Review, 2 (16), no. 4.

Batóg, B., Mojsiewicz, M., Wawrzyniak, K. (2009). Badanie rynku ubezpieczeń III filara z zastosowaniem analizy korespondencji. Prace Naukowe Uniwersytetu Ekonomicznego we Wrocławiu, 47.

Batóg, B., Mojsiewicz, M., Wawrzyniak, K. (2011). Segmentacja gospodarstw domowych ze względu na popyt potencjalny i zrealizowany na rynku ubezpieczeń życiowych w Polsce. Prace Naukowe Uniwersytetu Ekonomicznego we Wrocławiu, 176.

Bąk, I., Wawrzyniak, K. (2009). Zastosowanie analizy korespondencji w badaniach zawiązanych z motywami wyboru rodzajów wyjazdów turystycznych przez emerytów i rencistów w 2005 roku. Prace Naukowe Uniwersytetu Ekonomicznego we Wrocławiu, 47, 324-332.

Bąk, I., Wawrzyniak, K. (2010). Diagnoza wyjazdów turystycznych gospodarstw domowych emerytów i rencistów w Polsce z wykorzystaniem drzewa klasyfikacyjnego i regresyjnego. Prace Naukowe Uniwersytetu Ekonomicznego we Wrocławiu, 107.

Bąk, I., Wawrzyniak, K., Oesterreich, M. (2019). The Application of Statistical Methods to Identify Factors Determining Employment Effectiveness in District Labour Offices in Poland. Acta Universitatis Lodziensis. Folia Oeconomica, 4 (343).

Cheba, K., Hołub-Iwan, J. (2014). Wykorzystanie analizy korespondencji w segmentacji rynku usług medycznych. Prace Naukowe Uniwersytetu Ekonomicznego we Wrocławiu, 328.

Dębkowska, K., Kilon, J. (2014). Application of correspondence analysis to the identification of the determinants of the economic condition of the e-services sector enterprises in Podlaskie region. Ekonomia i Zarzadzanie, 1.

Dudek, A. (2011) Analiza danych symbolicznych w środowisku R. Podstawy metodologiczne i przykłady zastosowań. Prace Naukowe Uniwersytetu Ekonomicznego we Wrocławiu, 176. 
Durka, W. (2018). Ocena kondycji psychicznej, Raport końcowy dotyczacy zastosowania narzędzia samooceny zdrowia psychicznego. Szczecin: Stowarzyszenie Czas Przestrzeń Tożsamość.

Ezzari, A., Verme, P. (2012). A Multiple Correspondence Analysis Approach to the Measurement of Multidimensional Poverty in Morocco 2001-2007. Policy Research Working Paper, 6087, Washington: World Bank.

Freudenberger, H.J., North, G. (2002). Women's Burnout. How to Spot It, How to Reverse It and How to Prevent It. Doubleday. New York.

Gatnar, E. (2001). Nieparametryczna metoda dyskryminacji i regresji. Warszawa: Wydawnictwo Naukowe PWN.

Gatnar, E. (2008). Podejście wielomodelowe w zagadnieniach dyskryminacji i regresji. Warszawa: Wydawnictwo Naukowe PWN.

Gatnar, E., Walesiak, M. (eds.) (2004). Metody statystycznej analizy wielowymiarowej w badaniach marketingowych. Wrocław: Wydawnictwo Akademii Ekonomicznej.

Gatnar, E., Walesiak, M. (eds.) (2009). Statystyczna analiza danych z wykorzystaniem programu $R$. Warszawa: Wydawnictwo Naukowe PWN.

Greenacre, M. (1984). Theory Applications of Correspondence Analysis. London: Academic Press.

Greenacre, M. (1993). Correspondence Analysis in Practice. London: Academic Press.

Greenacre, M. (1994). Multiple and Joint Correspondence Analysis, In: M. Greenacre, J. Blasius (eds.), Correspondence Analysis in Social Sciences. Recent Developments and Applications. San Diego: Academic Press.

Grabiński, T. (1992). Metody taksonometrii. Kraków: Wydawnictwo Akademii Ekonomicznej w Krakowie.

Leiter, M.P., Harvie, P., Frizzell, C. (1998). The correspondence of patient satisfaction and nurse burnout. Social Science \& Medicine, 47 (10), 1611-1617.

Malina, A. (2004). Wielowymiarowa analiza przestrzennego zróżnicowania struktury gospodarki Polski według województw. Kraków: Wydawnictwo Akademii Ekonomicznej w Krakowie.

Maslach, Ch., Jackson, S.E. (1986). Maslach Burnout Inventory, Palo Alto. Consulting Psychologist Press.

Maslach, Ch. (1998). A Multidimensional Theory of Burnout. In: C.L. Cooper (ed.), Theories of organizational stress. New York: Oxford University Press.

Maslach, Ch., Leiter, M.P. (2001). Burnout and Health. In: A. Baum, T.A. Revenson, J.E. Singer (eds.), Handbook of Health Psychology. Mahwah: Lawrence Erlbaum Associates Publisher. 
Matczak, E., Kozłowski, W. (2013). Zastosowanie metody drzew klasyfikacyjnych w analizie aspiracji edukacyjnych rodziców. Warszawa: Instytut Badań Edukacyjnych.

Nahrgang, J.D., Morgeson, F.P., Hofmann, D.A. (2011). Safety at Work: A Meta-Analytic Investigation of the Link Between Job Demands, Job Resources, Burnout, Engagement, and Safety Outcomes. Journal of Applied Psychology, 96 (1), 71-94.

Ostrowska, M., Michcik, A. (2013). Wypalenie zawodowe - przyczyny, objawy, skutki, zapobieganie. Bezpieczeństwo Pracy - Nauka i Praktyka, 8 (503), 22-25.

Paoli, P. (1997). Second European survey on the work environment 1995. Dublin: European Foundation for the Improvement of Living and Working Conditions, Loughlinstown House.

Pines, A.M. (2004). Wypalenie - w perspektywie egzystencjalnej. In: H. Sęk (ed.), Wypalenie zawodowe. Przyczyny i zapobieganie. Warszawa: PWN.

Schaufeli, W.B., Bakker, A.B. (2004). Job demands, job resources, and their relationship with burnout and engagement: a multi-sample study. Journal of Organizational Behavior, 25.

Sekułowicz, M. (2002). Wypalenie zawodowe nauczycieli pracujacych z osobami z niepetnosprawnościa intelektualna. Przyczyny - symptomy - zapobieganie - przezwyciężanie. Wrocław: Wydawnictwo Uniwersytetu Wrocławskiego.

Sęk, H. (ed.) (2004). Wypalenie zawodowe. Przyczyny i zapobieganie. Warszawa: PWN.

Smith, M., Segal, J., Robinson, L. (2019). Burnout Prevention and Treatment, Help Guide. Retrieved from: https://www.helpguide.org/articles/stress/burnout-prevention-and-recovery. htm (30.03.2020).

Stanimir, A. (2005). Analiza korespondencji jako narzędzie do badania zjawisk ekonomicznych. Wrocław: Wydawnictwo Akademii Ekonomicznej.

StatSoft, (2006). Elektroniczny Podręcznik Statystyki PL. Kraków, WEB: http://www.statsoft. $\mathrm{pl} /$ textbook/stathome.html.

Świętochowski, W. (2011). Wypalenie zawodowe nauczycieli akademickich i nauczycieli szkoły średniej - analiza porównawcza. Medycyna Pracy, 62 (2).

Zbyrad, T. (2017). Ryzyko wypalenia zawodowego pracowników służb społecznych. Annales Universitatis Mariae Curie-Skłodowska. Sectio J, Paedagogia-Psychologia, 30 (4), 87-105. 